\title{
Chemical Composition and Anti-Inflammatory Activity of the Decoction from Leaves of a Cultivated Specimen of Myracrodruon urundeuva
}

\author{
Nayara C. Aquino, ${ }^{a, b}$ Emerson F. Queiroz, ${ }^{b}$ Laurence Marcourt, ${ }^{b}$ Lyara B. N. Freitas, ${ }^{c}$ \\ Emmanuel V. O. Araújo, ${ }^{c}$ Luzia K. A. M. Leal, ${ }^{c}$ Antonio M. E. Bezerra, ${ }^{d}$ Julien Boccard, ${ }^{b}$ \\ Jean-Luc Wolfender ${ }^{b}$ and Edilberto R. Silveira ${ }^{\circledR} * a$
}

${ }^{a}$ Departamento de Química Orgânica e Inorgânica, Universidade Federal do Ceará, Campus do Pici, Bloco 942, 60450-765 Fortaleza-CE, Brazil

${ }^{b}$ School of Pharmaceutical Sciences, Geneva-Lausanne School of Pharmacy (EPGL), University of Geneva, University of Lausanne, 30 Quai Ernest-Ansermet,

CH-1211 Geneva 4, Switzerland

${ }^{c}$ Centro de Estudos Farmacêuticos e Cosméticos (CEFAC), Departamento de Farmácia, Universidade Federal do Ceará, Rua Coronel Nunes de Melo, 1127, Rodolfo Teófilo, 60430-270 Fortaleza-CE, Brazil

${ }^{d}$ Departamento de Fitotecnia, Universidade Federal do Ceará, Av. Mister Hull, 2977, 60356-001 Fortaleza-CE, Brazil

\begin{abstract}
Myracrodruon urundeuva (Anacardiaceae) is the scientific designation of "aroeira-do-sertão", a tree well dispersed at the northeastern Brazil. The medicinal use of this plant is widespread throughout the rural population and the inner trunk bark decoction is used to treat cutaneous affections, urinary and respiratory diseases, and gynecological problems. "Aroeira-do-sertão" has been included in the list of native species under extinction threat. In order to find a sustainable source of the plant, seedlings have been cultivated. The purpose of this work was to investigate the chemical composition of the decoction from leaves of cultivated plants (aqueous extract from Myracrodruon urundeuva (AEMU)) and its anti-inflammatory activity on human neutrophils. The addition of AEMU on cells suspension inhibited significantly its activation/degranulation induced by phorbol myristate acetate. AEMU since at $50 \mu \mathrm{g} \mathrm{mL}^{-1}$ showed better pattern of inhibitions when related to indomethacin, nonselective cyclooxygenase inhibitor used as reference anti-inflammatory. The decoction fractionation was performed by high-speed counter-current chromatography (HSCCC) and semi-preparative highperformance liquid chromatography (HPLC) using a phenyl column as the stationary phase, allowing the isolation of 24 compounds. These results showed how the AEMU is rich in bioactive metabolites, which probably contribute for the anti-inflammatory effects of this plant extract, modulating the degranulation of human neutrophils, one of the pro-inflammatory mechanism of these cells.
\end{abstract}

Keywords: Myracrodruon urundeuva, high-speed counter-current chromatography, human neutrophils degranulation, anti-inflammatory activity

\section{Introduction}

Myracrodruon urundeuva Fr. Allem. (Anacardiaceae) is a tree, popularly known as "aroeira-do-sertão", widely found in "Caatinga" and other dry forests of Brazil, from Ceará to Paraná states, especially on the west of Bahia, Minas Gerais, and São Paulo, as well as on south of Mato Grosso do Sul, Mato Grosso, and Goiás. ${ }^{1}$ This plant has been used in traditional medicine to treat pains and

*e-mail: edil@ufc.br infections in general, vaginal discharge, asthma, cough, tuberculosis, bronchitis, heartburn, gastritis, toothache, placental delivery, anemia, diphtheria, skin ulcers, uterine, throat and ovarian inflammations. The stem bark is the plant part that is most used against those diseases, but the literature also reports the use of stem, leaf, and root. ${ }^{2}$

Previous works ${ }^{3-8}$ report on the phytochemical analysis and pharmacological activities of different extracts from leaves of $M$. urundeuva. Lectins, isolated from a saline solution from dried leaves, showed anthelmintic, ${ }^{3}$ insecticidal, ${ }^{3}$ and larvicidal activity. ${ }^{4} \mathrm{~A}$ study performed 
with the leaf ethanol extract showed antibacterial activity and a phytochemical screening suggested the presence of hydrolyzable tannins, anthocyanins, anthocyanidins, flavones, flavonols, xanthones, chalcones, aurones, flavanonols, leucoanthocyanidins, catechins, and flavanones. ${ }^{5}$ In another study, fractions of the ethanol extract from dried leaves showed antiviral activity against rotavirus, and the phytochemical screening of these fractions suggested the presence of terpenes, flavonoids, and tannins as the major secondary metabolites. ${ }^{6}$ In another phytochemical screening of the hydroalcohol extract, it has been suggested the presence of saponins, flavonoids, and tannins as the major secondary metabolites. ${ }^{7}$ Silva et $a l .{ }^{8}$ have investigated the hydrolysable tannins present in the ethanol extract by dereplication through matrix assisted laser desorption/ionization-time-of-flight mass spectrometry (MALDI-TOF-MS). Despite all these records, no secondary metabolites have ever been isolated, and characterized, from leaf extracts of $M$. urundeuva.

Previous studies ${ }^{9-12}$ with wild $M$. urundeuva or its secondary metabolites have demonstrated their antioxidant and/or anti-inflammatory activities, but biological studies with cultivated plants are inexistent, particularly when referring to the leaves of cultivated specimens. M. urundeuva is known to be rich in tannins and bichalconoids that have been designated urundeuvines $\mathrm{A}-\mathrm{C}$, and another one designated matosine, which are allegedly the main compounds responsible for the antiinflammatory, antinociceptive, and antiulcer properties of the hydroalcohol trunk bark extract. ${ }^{13,14}$

This work reports the chemical composition and anti-inflammatory activity of the decoction from leaves of cultivated specimens of $M$. urundeuva, obtained after the essential oil extraction by hydrodistillation. The chromatographic fractionation by high-speed countercurrent chromatography (HSCCC) and semi-preparative high-performance liquid chromatography (HPLC), using a phenyl column as stationary phase, allowed the isolation and structure characterization of 24 compounds belonging to different secondary metabolite classes like phenol derivatives, hydrolysable tannins, flavonoid glycosides, and megastigmanes.

\section{Experimental}

\section{General experimental procedures}

The 1D and 2D nuclear magnetic resonance (NMR) spectra were acquired on a $500 \mathrm{MHz}$ Varian Inova spectrometer (Palo Alto, CA, USA), using $\mathrm{CD}_{3} \mathrm{OD}$ as solvents. Chemical shifts $(\delta)$ were reported in parts per million using the residual $\mathrm{CD}_{3} \mathrm{OD}$ signal $\left(\delta_{\mathrm{H}} 3.31 ; \delta_{\mathrm{C}} 49.0\right)$ as an internal standard for ${ }^{1} \mathrm{H}$ and ${ }^{13} \mathrm{C}$ NMR, respectively. HSCCC analysis was performed on a Tauto instrument (Shangai, China, coil volume: $260 \mathrm{~mL}$; loop sample: $20 \mathrm{~mL}$ ) equipped with two Shimadzu LC-10AD pumps and a Knauer UV detector. Semi-preparative HPLC analyses were carried out with a Shimadzu LC-8A (Columbia, MD, USA) equipped with a UV detector.

Ultra high-performance liquid chromatography-photodiode array-evaporative light scattering detector (UHPLC-PDAELSD) analyses

UHPLC-PDA-ELSD data were obtained with an Agilent HP 1100 series system consisting of an auto sampler, high-pressure mixing pump and diode array detector (DAD, Agilent Technologies, Santa Clara, CA, USA) connected to an ELSD detector Sedex 85 (Sedere, Olivet, France). The UHPLC conditions were as follow: an Acquity BEH $\mathrm{C}_{18}$ UPLC column $(1.7 \mu \mathrm{m}$, $150 \times 2.1 \mathrm{~mm}$, i.d.; Waters, Milford, USA); the solvent system used was (A) $\mathrm{MeOH}$ and (B) $\mathrm{H}_{2} \mathrm{O}$; gradient: 5 to $95 \%$ of A in 4 min followed by 95 to $100 \%$ of A for $2 \mathrm{~min}$; flow rate: $0.46 \mathrm{~mL} \mathrm{~min}^{-1}$; injection volume: $1 \mu \mathrm{L}$; and sample concentration: $1 \mathrm{mg} \mathrm{mL}^{-1}$ in $\mathrm{MeOH}$. The column was used at the room temperature at $40^{\circ} \mathrm{C}$. The UV absorbance was measured at 210 and $254 \mathrm{~nm}$, and UV spectra (PDA) were recorded between 190 and $600 \mathrm{~nm}$ (in increments of $2 \mathrm{~nm}$ ). The ELSD (Sedex 85, Sedere Omnilab, Altfortville, France) conditions were: temperature of $50^{\circ} \mathrm{C}$, gain of 7 and $\mathrm{N}_{2}$ as nebulization gas.

\section{UHPLC-PDA-high-resolution mass spectrometry (HRMS)}

HRMS metabolite profiling of the extracts was performed on a Micromass-LCT Premier time of flight (TOF) mass spectrometer (Waters, Milford, MA, USA) equipped with an electrospray interface and coupled to an Acquity UPLC system (Waters, Milford, MA, USA). The electrospray ionization (ESI) conditions were as follows: capillary voltage, $2800 \mathrm{~V}$; cone voltage, $40 \mathrm{~V}$; microchannel plate (MCP) detector voltage, $2400 \mathrm{~V}$; source temperature, $120{ }^{\circ} \mathrm{C}$; desolvation temperature, $350{ }^{\circ} \mathrm{C}$; cone gas flow, $20 \mathrm{~L} \mathrm{~h}^{-1}$, and desolvation gas flow, $800 \mathrm{~L} \mathrm{~h}^{-1}$. Detection was performed in positive ion (PI) and negative ion modes (NI) with an $\mathrm{m} / \mathrm{z}$ range of $100-1000 \mathrm{amu}$ and a scan time of $0.5 \mathrm{~s}$ in the W-mode. The MS was calibrated using sodium formate. Leucine-encephalin (Sigma-Aldrich, Steinheim, Germany) was used as an internal reference at $2 \mu \mathrm{g} \mathrm{mL}^{-1}$ and infused through a Lock Spray ${ }^{\mathrm{TM}}$ probe at a flow rate of $10 \mu \mathrm{L} \mathrm{min}{ }^{-1}$ with the help of a second $\mathrm{LC}$ 
pump. The separation was performed on an Acquity BEH $\mathrm{C}_{18}$ UPLC column $(1.7 \mu \mathrm{m}, 150 \times 2.1 \mathrm{~mm}$, i.d.; Waters, Milford, USA) using a linear gradient. The solvent system used was (A) $\mathrm{MeOH}$ and (B) $\mathrm{H}_{2} \mathrm{O}$; gradient: 5 to $95 \%$ of A in $30 \mathrm{~min}$; followed by $95 \%$ of A for $10 \mathrm{~min}$ at a constant flow rate of $0.46 \mathrm{~mL} \mathrm{~min}{ }^{-1}$. Fifty percent of the column flow was split by a T-tube before the ESI probe. The column was used at $40{ }^{\circ} \mathrm{C}$. The injected volume was $1 \mu \mathrm{L}$. All instruments were controlled by MassLynx software, version 4.1. The molecular formulae and isotope pattern scores were calculated using the elemental composition module, version 4.0 (Waters, Milford, MA, USA).

\section{Plant material}

Myracrodruon urundeuva was cultivated in the horticulture sector of the Federal University of Ceará (Fortaleza, Brazil) in February 2012. The propagation of plants was made by sowing seeds acquired from wild specimens. The leaves of cultivated specimens were collected from 3 years old plants.

\section{Extraction}

Fresh leaves $(600 \mathrm{~g})$ of $M$. urundeuva were submitted to hydrodistillation, with $2.5 \mathrm{~L}$ of distilled water, over a period of $2 \mathrm{~h}$, obtaining $0.8 \mathrm{~mL}$ of essential oil, composed mainly by mircene, and $2.3 \mathrm{~L}$ of the decoction liquids. The latter was lyophilized yielding $83.1 \mathrm{~g}$.

Isolation

The lyophilized decoction was fractionated by HSCCC using an F Arizona system (hexane/EtOAc/MeOH/ $\mathrm{H}_{2} \mathrm{O}$, 1:5:1:5), a methodology described by Margraff. ${ }^{15}$ For the separation, the coil was filled with the stationary phase (lower phase), the speed rotation was set to $900 \mathrm{rpm}$, after the mobile phase (upper phase) was pumped with the flow of $3.0 \mathrm{~mL} \mathrm{~min}^{-1}$ into the column using the mode tail to head. After the equilibration between the phases, the decoction $(4.0 \mathrm{~g}$ ) was solubilized in $20 \mathrm{~mL}$ of both upper and lower phases $(10 \mathrm{~mL}$ each), and then injected through the column. The fraction volumes were $150 \mathrm{~mL}(\mathrm{~F} 1)$, $3.0 \mathrm{~mL}$ (F2-176), $45 \mathrm{~mL}$ (F177) and $3.0 \mathrm{~mL}$ (F178-190). After fraction 176, the rotation was inverted to head to tail. The 190 fractions were analyzed by UHPLC-PDAELSD. Fractions F3 and F57 correspond to compounds 13 and 3, respectively. Fraction F48 corresponds to a mixture of compounds $\mathbf{6}$ and $\mathbf{7}$, while F181 corresponds to a mixture of two compounds that were separated through a Sephadex LH-20 column (Merck, Darmstadt, Germany), yielding $\mathbf{1}$ and 2. Fractions F34-43, F71-109 and F122-177 were purified by semi-preparative HPLC using a phenyl column $(250 \times 9.5 \mathrm{~mm}, 5 \mu \mathrm{m}$, Agilent, Santa Clara, USA $)$. Fractions F34-43 were eluted with a mixture of $\mathrm{H}_{2} \mathrm{O}$ (A) and $\mathrm{MeCN}$ (B) as eluent with $0.1 \% \mathrm{FA}$, in gradient conditions: 20 to $80 \%$ of B in 40 min, yielding $4(2.8 \mathrm{mg}$, retention time $\left.\left(\mathrm{t}_{\mathrm{R}}\right)=4.6 \mathrm{~min}\right), \mathbf{5}\left(1.1 \mathrm{mg}, \mathrm{t}_{\mathrm{R}}=5.2 \mathrm{~min}\right), \mathbf{6}$ and $7\left(2.8 \mathrm{mg}, \mathrm{t}_{\mathrm{R}}=5.8 \mathrm{~min}\right), \mathbf{2 2}\left(0.9 \mathrm{mg}, \mathrm{t}_{\mathrm{R}}=14.6 \mathrm{~min}\right)$, $23\left(1.0 \mathrm{mg}, \mathrm{t}_{\mathrm{R}}=15.4 \mathrm{~min}\right)$ and $\mathbf{2 4}\left(0.7 \mathrm{mg}, \mathrm{t}_{\mathrm{R}}=16.6 \mathrm{~min}\right)$. Fractions F71-109 were eluted using a mixture of $\mathrm{H}_{2} \mathrm{O}$ (A) and $\mathrm{MeOH}(\mathrm{B})$, both with $0.1 \% \mathrm{FA}$, in gradient conditions: 30 to $60 \%$ of $\mathrm{B}$ in $50 \mathrm{~min}$, yielding $8\left(2.8 \mathrm{mg}, \mathrm{t}_{\mathrm{R}}=7.6 \mathrm{~min}\right)$, $\mathbf{1 2}\left(2.0 \mathrm{mg}, \mathrm{t}_{\mathrm{R}}=9.2 \mathrm{~min}\right), \mathbf{1 7}$ and $\mathbf{1 8}\left(2.4 \mathrm{mg}, \mathrm{t}_{\mathrm{R}}=21.0 \mathrm{~min}\right)$, $16\left(25.1 \mathrm{mg}, \mathrm{t}_{\mathrm{R}}=26.5 \mathrm{~min}\right)$ and $\mathbf{2 0}\left(19.0 \mathrm{mg}, \mathrm{t}_{\mathrm{R}}=31.2 \mathrm{~min}\right)$. Fractions F122-177 were purified using the same eluent mixture used to F34-43, but in other isocratic conditions: $40 \%$ of B, yielding $\mathbf{9}\left(2.0 \mathrm{mg}, \mathrm{t}_{\mathrm{R}}=5.0 \mathrm{~min}\right), \mathbf{1 0}(2.9 \mathrm{mg}$, $\left.\mathrm{t}_{\mathrm{R}}=6.3 \mathrm{~min}\right), \mathbf{1 5}\left(1.3 \mathrm{mg}, \mathrm{t}_{\mathrm{R}}=13.2 \mathrm{~min}\right), \mathbf{1 4}(1.2 \mathrm{mg}$, $\left.\mathrm{t}_{\mathrm{R}}=14.5 \mathrm{~min}\right), \mathbf{1 1}\left(0.9 \mathrm{mg}, \mathrm{t}_{\mathrm{R}}=18.0 \mathrm{~min}\right), \mathbf{2 1}(1.0 \mathrm{mg}$, $\left.\mathrm{t}_{\mathrm{R}}=21.0 \mathrm{~min}\right)$ and $\mathbf{1 9}\left(0.6 \mathrm{mg}, \mathrm{t}_{\mathrm{R}}=27.9 \mathrm{~min}\right)$.

\section{Isolation of human neutrophils}

Human leucocyte-rich blood from healthy adults was obtained from HEMOCE (blood bank), Fortaleza, CE, Brazil. Neutrophils were isolated by Lucisano and Mantovani's method ${ }^{16}$ with slight modifications (Kabeya and co-workers) ${ }^{17}$ In the present study, the cells suspension contained $80-90 \%$ neutrophils with viability of $89 \pm 2.0 \%$ established by exclusion with trypan blue used in the study.

\section{Degranulation assay}

Following Boyum, ${ }^{18} 5 \times 10^{6}$ cells $\mathrm{mL}^{-1}$ were suspended in buffered Hank's balanced salt solution (HBSS). The cells were incubated with the decoction from leaves of M. urundeuva (AEMU) (1-100 $\mu \mathrm{g} \mathrm{mL}^{-1}$ ), saline (control group), indomethacin ( $36 \mu \mathrm{g} \mathrm{mL} \mathrm{m}^{-1}$, standard drug) or HBSS (negative control group) for $15 \mathrm{~min}$ at $37^{\circ} \mathrm{C}$. Human neutrophils were stimulated by phorbol myristate acetate (PMA) $(0.1 \mu \mathrm{M})$ for $15 \mathrm{~min}$ at $37^{\circ} \mathrm{C}$. The reaction was stopped by cooling and the suspension was centrifuged at $2000 \times \mathrm{g}$ for $10 \mathrm{~min}$ at $4{ }^{\circ} \mathrm{C}$. Aliquots $(50 \mu \mathrm{L})$ of the supernatants were added to phosphate buffered saline [PBS $(100 \mu \mathrm{L})]$, phosphate buffer $(50 \mu \mathrm{L}, \mathrm{pH} 7.0)$ and $\mathrm{H}_{2} \mathrm{O}_{2}(0.012 \%)$. After $5 \mathrm{~min}$ at $37^{\circ} \mathrm{C}, 3,3^{\prime}, 5,5^{\prime}$-tetramethylbenzidine $(1.5 \mathrm{mM}$, $20 \mu \mathrm{L}$ ) was added, and the reaction was stopped with $30 \mu \mathrm{L}$ of sodium acetate (1.5 M, pH 3.0). The results are expressed as percentage of the release of myeloperoxidase (MPO) by stimulated human neutrophils. 


\section{Cytotoxic studies}

Lactate dehydrogenase (LDH) assay

Human neutrophils $\left(2.5 \times 10^{6}\right.$ cells $\left.\mathrm{mL}^{-1}\right)$ in a suspension were incubated with the AEMU (1-100 $\left.\mu \mathrm{g} \mathrm{mL}^{-1}\right)$, saline (control group), HBSS (not treated cells) or Triton X-100 $\left(0.2 \% \mathrm{v} / \mathrm{v}\right.$, cytotoxic drug) for $15 \mathrm{~min}$ at $37^{\circ} \mathrm{C}$. The $\mathrm{LDH}$ activity was determined by a commercially available method (LDH liquiform of Labtest Diagnosis, Lagoa Santa, MG, Brazil).

\section{Statistical analysis}

The results are expressed as mean \pm S.E.M. (standard error of the mean). The statistical significance of differences between groups was determined by one-way ANOVA, followed by Tukey for multiple comparisons as a post hoc test. The significance level was set at $p<0.05$.

\section{Results and Discussion}

Fresh leaves from a 3 years old cultivated specimen of M. urundeuva were submitted to hydrodistillation leading to the essential oil and a residue that was filtrated to yield the decoction liquid. The decoction liquid was lyophilized and submitted to an UHPLC-PDA-HRMS analysis (Figure 1). This analysis showed the presence of some compounds with MS and UV characteristic of gallotannins and other phenol derivatives (Table S1, Supplementary Information (SI) section), which was in agreement with previous dereplication studies with the leaf ethanol extract performed by Silva et al. ${ }^{8}$
The water decoction is a very polar extract and the isolation of the compounds from this extract should be difficult under regular chromatographic conditions. In order to avoid irreversible adsorption that can occur on silica gel columns, the decoction was fractionated by high-speed counter-current chromatography coupled to the UV detection (HSCCC-UV). The biphasic solvent system was selected using the Arizona methodology described by Margraff, ${ }^{15}$ which uses a quaternary solvent system composed by $n$-heptane-EtOAc (upper phase) and $\mathrm{MeOH}$-water (lower phase) with 23 different proportions (fractions A to Z). ${ }^{15} 1 \mathrm{mg}$ of the extract was used for each system. After thoroughly equilibrating the solvent mixtures in a separatory funnel at room temperature, two phases were collected separately, dried and analyzed by HPLC-PAD (Figure S1, SI section). The partition coefficient (Kp) was calculated based on the area of each of the peak detected by UV. As a result, the system of solvent selected was composed of hexane/EtOAc/MeOH/ $\mathrm{H}_{2} \mathrm{O}$ (1:5:1:5). After separation, the HSCCC fractions were monitored by UHPLC-PDA-ELSD using a fast gradient of 2 min. By these means all of the 180 HSCCC fractions were monitorated in $6 \mathrm{~h}$. For the best visualization of the results, the data were organized in a 2D map (Figure 2). This map shows the contour plot of all the HSCCC fractions with the respective UHPLC-ELSD profile. The $2 \mathrm{D}$ plot shows, for example, that the HSCCC fractions IV and I contain compounds $\mathbf{3}$ and $\mathbf{1 3}$ in pure form, respectively. The other fractions are still complex mixtures. These fractions, containing close related compounds, were too difficult of being purified using a classical reverse phase $\mathrm{C} 18$ column. For this reason different columns were tested. The best

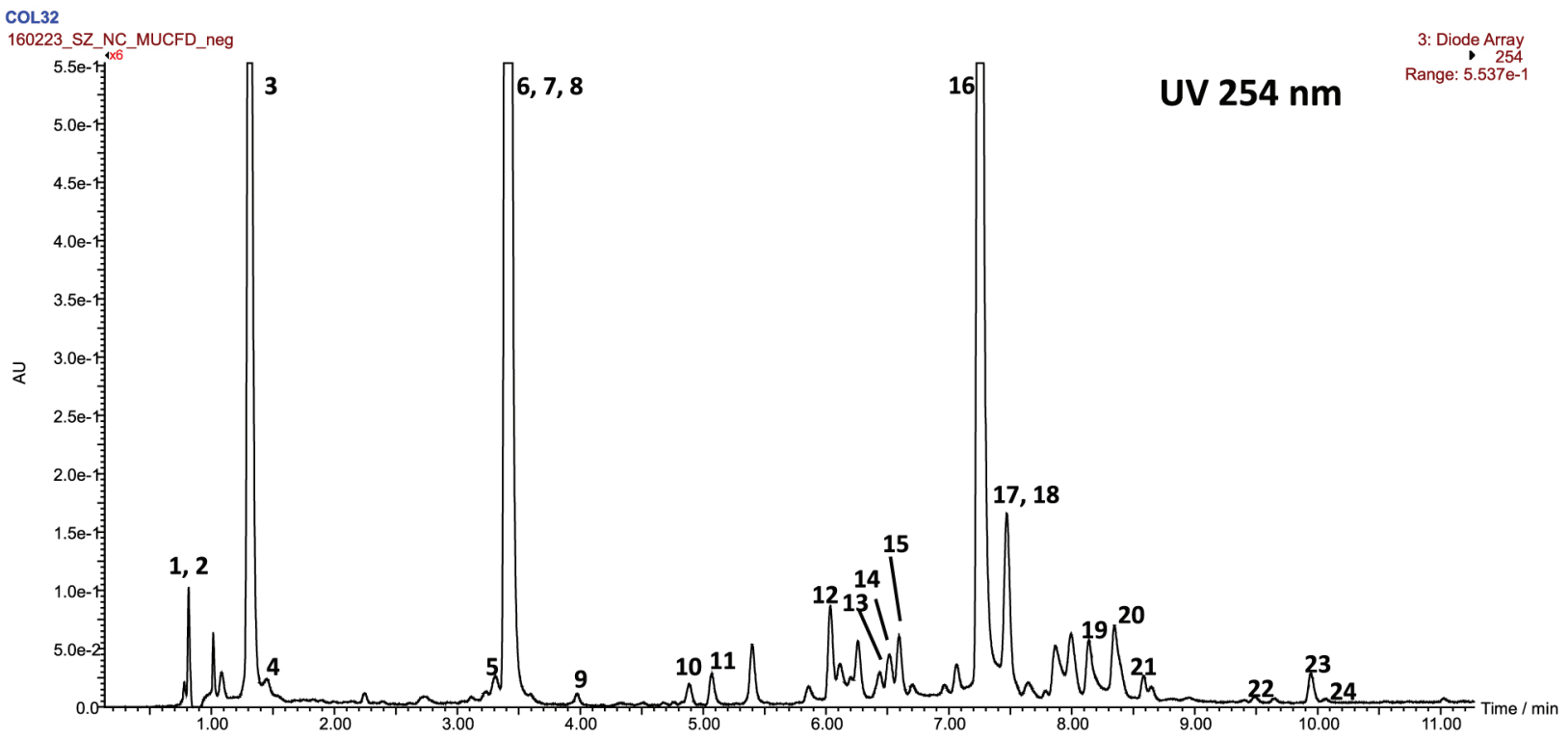

Figure 1. UHPLC-PDA chromatogram (UV $254 \mathrm{~nm}$ ) of the decoction from the leaves of cultivated M. urundeuva. 


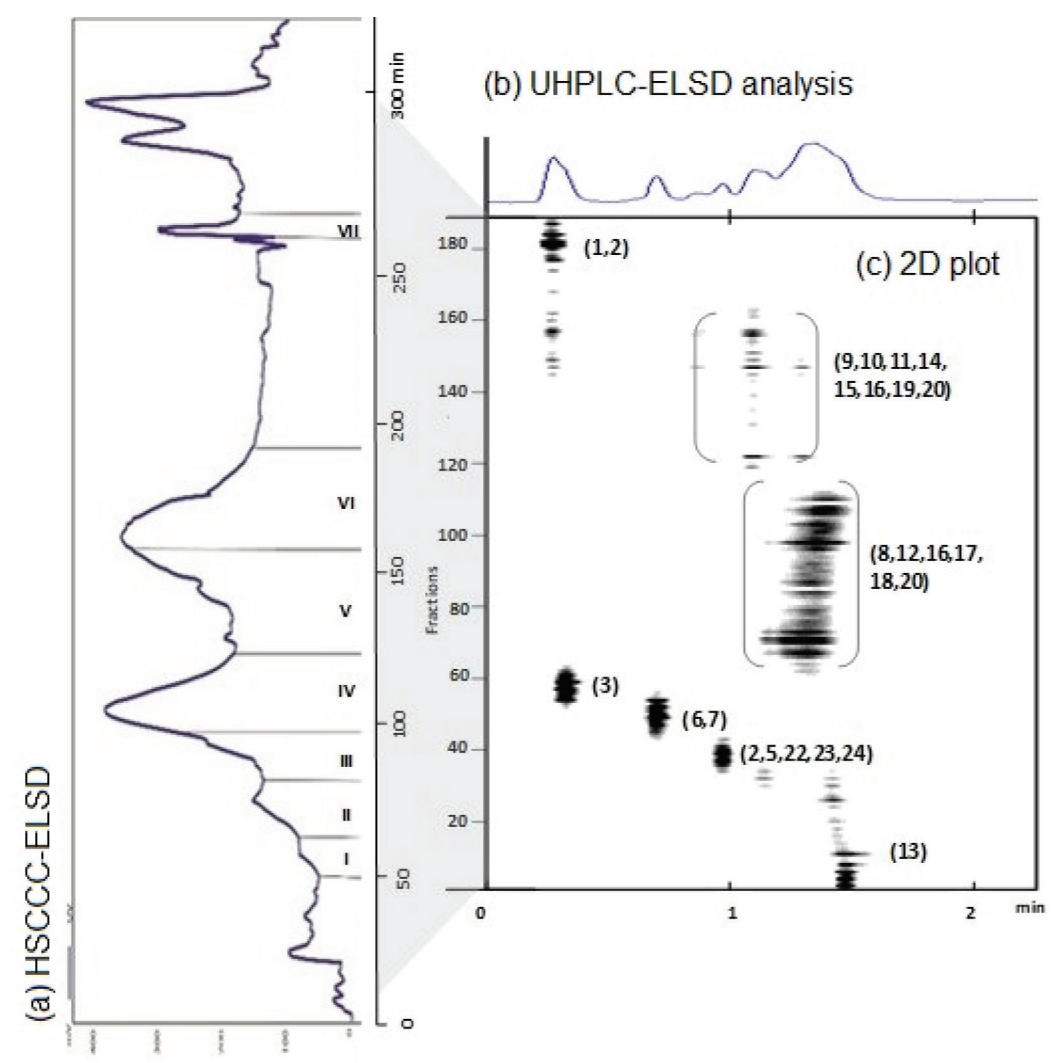

Figure 2. (a) HSCCC-ELSD and (b) UHPLC-ELSD chromatograms; (c) 2D HSCCC vs. UHPLC map for post-chromatographic monitoring of the HSCCC fractions obtained from the leaf decoction of M. urundeuva. The number in the 2D plot correspond to the isolated compounds (1-24).

results were obtained with the phenyl stationary phase. The phenyl column showed to be extremely efficient to perform the purification of all sets of mixtures of high polar compounds present in the HSCCC fractions.

Using this approach, twenty-four known compounds were isolated and identified from the leaf decoction of M. urundeuva. These compounds belong to different class of metabolites: a non-proteic amino acid (1), a carboxylic acid (2), eight polyphenol carboxylic acid derivatives $(3,4,5,6,7,8,17$ and 18), a flavonoid (13), seven flavonoids glycosides $(11,14,15,19,22,23$ and 24), four gallotannins $(9,12,16$ and 20) and two megastigmane (10 and 21). Each isolated constituent was identified by MS and MS/MS fragmentation and the structure confirmed by NMR analyses, including ${ }^{1} \mathrm{H}$, correlation spectroscopy (COSY), heteronuclear single quantum correlation spectroscopy (HSQC), heteronuclear multiple bond correlation spectroscopy (HMBC) and nuclear Overhauser effect spectroscopy (NOESY) experiments. The data are described in SI section (Figures S2-S78 and Tables S2-S24). Figure 1 shows the leaf decoction HPLC chromatogram indicating all the isolated compounds (Figure 3).

Compounds $\mathbf{1}$ and $\mathbf{2}$ showed the mass spectra with $\mathrm{m} / \mathrm{z}$ $146.08[\mathrm{M}+\mathrm{H}]^{+}\left(\mathrm{C}_{6} \mathrm{H}_{12} \mathrm{NO}_{3}\right)$ and $192.13[\mathrm{M}-\mathrm{H}]^{-}\left(\mathrm{C}_{7} \mathrm{H}_{11} \mathrm{O}_{5}\right)$, respectively. Their 1D and 2D NMR data were compatible with the structures of the $\mathrm{N}$-methyl-trans-4-hydroxyL-proline (1) and quinic acid (2), respectively. The relative stereochemistry of all stereogenic centers was suggested based on the observed $J$ values for the scalar couplingsplitting pattern and by the NOESY spectrum analysis. Compounds $\mathbf{1}$ and $\mathbf{2}$, very common in plants, are the major components of the decoction from leaves of M. urundeuva.

The ${ }^{1} \mathrm{H}$ NMR spectra of the compounds 3-5 showed only signals in the aromatic region. Their mass spectra showed $m / z 169.01\left([\mathrm{M}-\mathrm{H}]^{-}, \mathrm{C}_{7} \mathrm{H}_{5} \mathrm{O}_{5}\right), 125.02\left([\mathrm{M}-\mathrm{H}]^{-}\right.$, $\left.\mathrm{C}_{6} \mathrm{H}_{6} \mathrm{O}_{3}\right)$ and $153.01\left([\mathrm{M}-\mathrm{H}]^{-}, \mathrm{C}_{7} \mathrm{H}_{6} \mathrm{O}_{4}\right)$, respectively. They were identified as the phenol compounds: gallic acid (3), pyrogallol (4) and protocatechuic acid (5). In addition, a mixture of $m$-digallic acid $\left(\mathrm{m} / \mathrm{z} 321.03,[\mathrm{M}-\mathrm{H}]^{-}\right)(\mathbf{6})$ and $p$-digallic acid $\left(\mathrm{m} / \mathrm{z}, 321.03,[\mathrm{M}-\mathrm{H}]^{-}\right)(7)$, and the methyl esthers: methyl gallate $\left(\mathrm{m} / \mathrm{z}, 183.03,[\mathrm{M}-\mathrm{H}]^{-}\right)(\mathbf{8})$, methyl $m$-digallate $\left(\mathrm{m} / \mathrm{z} 335.89,[\mathrm{M}-\mathrm{H}]^{-}\right)(\mathbf{1 7})$ and methyl p-digallate $\left(\mathrm{m} / \mathrm{z} 335.89,[\mathbf{M}-\mathbf{H}]^{-}\right)(\mathbf{1 8})$, were also isolated.

The ${ }^{1} \mathrm{H}$ NMR spectra of compounds $12(\mathrm{~m} / \mathrm{z}, 787.10$, $\left.[\mathrm{M}-\mathrm{H}]^{-}\right)$and $\left.\mathbf{1 6}(\mathrm{m} / \mathrm{z} \text { 939.11, [M - H] }]^{-}\right)$showed a higher similarity, both spectra showed several singlets in the aromatic region (four singlets for $\mathbf{1 2}$ and five singlets for 16, integrating for two protons), and multiplets between 6.25 and $4.35 \mathrm{ppm}$. Further, these compounds showed similar MS/MS fragmentation $(\mathrm{m} / \mathrm{z}, 169,295,465$ and 
<smiles>CN1C[C@H](O)C[C@H]1C(=O)O</smiles><smiles>O=C(O)[C@]1(O)C[C@@H](O)[C@H](O)C[C@H]1O</smiles><smiles>[R]c1cc([R])c([R1])c([R])c1[R]</smiles>

$$
\begin{aligned}
& 3 \mathrm{R}_{1}=\mathrm{COOH} ; \mathrm{R}_{2}=\mathrm{H} ; \mathrm{R}_{3}=\mathrm{R}_{4}=\mathrm{R}_{5}=\mathrm{OH} \\
& 4 \mathrm{R}_{1}=\mathrm{R}_{2}=\mathrm{H} ; \mathrm{R}_{3}=\mathrm{R}_{4}=\mathrm{R}_{5}=\mathrm{OH} \\
& \mathbf{5} \mathrm{R}_{1}=\mathrm{COOH} ; \mathrm{R}_{2}=\mathrm{R}_{5}=\mathrm{H} ; \mathrm{R}_{3}=\mathrm{R}_{4}=\mathrm{OH} \\
& \mathbf{8} \mathrm{R}_{1}=\mathrm{COOCH}_{3} ; \mathrm{R}_{2}=\mathrm{H} ; \mathrm{R}_{3}=\mathrm{R}_{4}=\mathrm{R}_{5}=\mathrm{OH}
\end{aligned}
$$<smiles>[R20]c1cc(C(=O)OCC)cc(O)c1O</smiles>

$6 \mathrm{R}_{1}=\mathrm{R}_{3}=\mathrm{H} ; \mathrm{R}_{2}=$ galloyl

$7 \mathrm{R}_{1}=\mathrm{R}_{2}=\mathrm{H} ; \mathrm{R}_{3}=$ galloyl

$17 \mathrm{R}_{1}=\mathrm{CH}_{3} ; \mathrm{R}_{2}=$ galloyl; $\mathrm{R}_{3}=\mathrm{H}$

$18 \mathrm{R}_{1}=\mathrm{CH}_{3} ; \mathrm{R}_{2}=\mathrm{H} ; \mathrm{R}_{3}=$ galloyl<smiles>[R2]c1cc(-c2oc3cc([R20])c([R2])c(O)c3c(=O)c2[R])ccc1O</smiles>

$11 \mathrm{R}_{1}=\mathrm{R}_{2}=\mathrm{R}_{3}=\mathrm{H} ; \mathrm{R}_{4}=$ O-rutinosyl

$13 \mathrm{R}_{1}=\mathrm{OH} ; \mathrm{R}_{2}=\mathrm{R}_{3}=\mathrm{H} ; \mathrm{R}_{4}=\mathrm{OH}$

$14 \mathrm{R}_{1}=\mathrm{H} ; \mathrm{R}_{2}=\beta$-D-glucosyl; $\mathrm{R}_{3}=\mathrm{H} ; \mathrm{R}_{4}=\mathrm{H}$

$15 \mathrm{R}_{1}=\mathrm{OH} ; \mathrm{R}_{2}=\mathrm{H} ; \mathrm{R}_{3}=\mathrm{H} ; \mathrm{R}_{4}=\mathrm{O}-\beta-\mathrm{D}$-glucosyl

$19 \mathrm{R}_{1}=\mathrm{H} ; \mathrm{R}_{2}=\mathrm{H} ; \mathrm{R}_{3}=2-\mathrm{O}$-(6-deoxy- $\alpha$-L-mannopyranosyl)- $\beta$-D-glucopyranosyl; $\mathrm{R}_{4}=\mathrm{H}$

$22 \mathrm{R}_{1}=\mathrm{OH} ; \mathrm{R}_{2}=\mathrm{H} ; \mathrm{R}_{3}=\mathrm{H} ; \mathrm{R}_{4}=\mathrm{O}-\left(2^{\prime \prime}\right.$-galloyl $)-\beta-\mathrm{D}$-arabinofuranosyl

$23 \mathrm{R}_{1}=\mathrm{OH} ; \mathrm{R}_{2}=\mathrm{H} ; \mathrm{R}_{3}=\mathrm{H} ; \mathrm{R}_{4}=\mathrm{O}$-(2"-galloyl)- $\beta$-L-rhamnopyranosyl

$24 \mathrm{R}_{1}=\mathrm{OH} ; \mathrm{R}_{2}=\mathrm{H} ; \mathrm{R}_{3}=\mathrm{H} ; \mathrm{R}_{4}=\mathrm{O}$-(3"-galloyl)- $\beta$-L-rhamnopyranosyl<smiles>CC1=CC(=O)CC(C)(C)[C@H]1/C=C/[C@H](C)O[C@@H]1O[C@H](CO)[C@@H](O)[C@H](O)[C@H]1O</smiles>

21<smiles>O=C(O[C@@H]1O[C@H](COC(=O)c2cc(O)c(O)c3oc(=O)c4cc(O)c(O)c(O)c4c23)[C@@H](O)[C@@H](O)[C@H]1O)c1cc(O)c(O)c(O)c1</smiles>

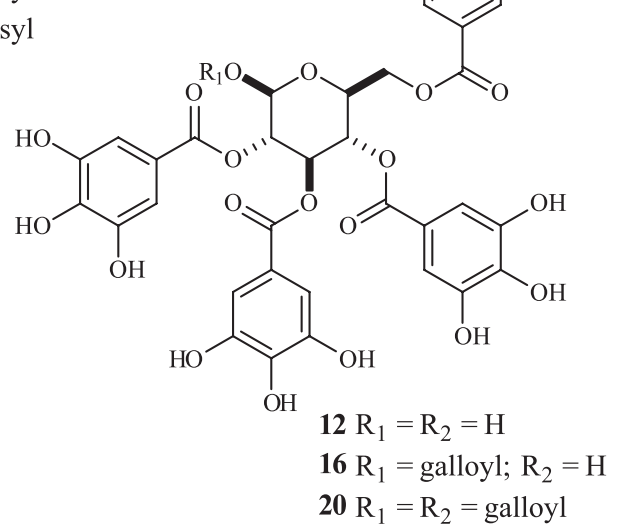

Figure 3. Structures of the compounds (1-24) isolated from the decoction of the leaves of a cultivated specimen of M. urundeuva.

617). Thus, compounds $\mathbf{1 2}$ and $\mathbf{1 6}$ were identified as the gallotannins 2,3,4,6-tetra- $O$-galloyl- $\beta$-D-glucopyranose $\left(\mathrm{m} / \mathrm{z}\right.$ 787.10, $\left.[\mathrm{M}-\mathrm{H}]^{-}\right)$and 1,2,3,4,6-penta- $O$-galloyl$\beta$-D-glucopyranose, respectively $\left(\mathrm{m} / \mathrm{z}\right.$ 939.11, $\left.[\mathrm{M}-\mathrm{H}]^{-}\right)$. The ${ }^{1} \mathrm{H}$ NMR spectrum of the compound $\mathbf{2 0}$ was similar to that of 16. The difference of mass between these compounds was $152 \mathrm{Da}$, showing that $\mathbf{2 0}$ had an extra galloyl unit, so 20 was identified as the 3-O-( $m$-digalloyl)-1,2,4,6-tetra$O$-galloyl- $\beta$-D-glucopyranose $\left(\mathrm{m} / \mathrm{z}\right.$ 1091.13, $\left.[\mathrm{M}-\mathrm{H}]^{-}\right)$. Compound 9 also showed the ${ }^{1} \mathrm{H}$ NMR spectrum similar to those of 12, 16 and 20, but only three singlets in the aromatic region, one of them integrating for two hydrogens and the two others integrating for one hydrogen. After all NMR analyses, compound $\mathbf{9}$ was identified as 1- $O$-galloyl6-O-luteoyl- $\alpha$-glucose $\left(\mathrm{m} / \mathrm{z}\right.$ 633.07, $\left.[\mathrm{M}-\mathrm{H}]^{-}\right)$.
After MS/MS and ${ }^{1} \mathrm{H}$ NMR analyses, compound $\mathbf{1 3}$ was characterized as quercetin $\left(\mathrm{m} / \mathrm{z}, 301.03,[\mathrm{M}-\mathrm{H}]^{-}\right)$. The NMR data of compounds 15, 22, 23 and 24 showed the same signals like quercetin, but with different substituents attached to C-3. These compounds were identified as quercetin 3-O- $\beta$-D-glucoside $\left(\mathrm{m} / \mathrm{z}\right.$ 477.07, $\left.[\mathrm{M}-\mathrm{H}]^{-}\right)$ (15), quercetin 3-O-(2"'-galloyl)- $\beta$-D-arabinofuranoside $\left.(\mathrm{m} / \mathrm{z} \text { 585.09, [M - H }]^{-}\right)(\mathbf{2 2})$, quercetin 3-O-(2"'-galloyl)$\alpha$-L-rhamnopyranoside $\left(\mathrm{m} / \mathrm{z}\right.$ 599.11, $\left.[\mathrm{M}-\mathrm{H}]^{-}\right)(\mathbf{2 3})$, and quercetin 3-O-(3")-galloyl)- $\alpha$-L-rhamnopyranoside $\left.(\mathrm{m} / \mathrm{z} \text { 599.11, [M - H }]^{-}\right)(\mathbf{2 4})$.

The NMR data of compounds 11, 14 and 19 showed signals referent to a kaempferol moiety, but with other signals of several substituents at different positions of the kaempferol unit, which was solved by HMBC. Thus, 11, 
14 and 19 were identified as kaempferol 3-O-rutinoside $\left(\mathrm{m} / \mathrm{z}\right.$ 593.15, [M-H]-), homovitexin $\left(\mathrm{m} / z\right.$ 431.10, $\left.[\mathrm{M}-\mathrm{H}]^{-}\right)$ and rhoifolin $\left(\mathrm{m} / \mathrm{z} 577.16,[\mathrm{M}-\mathrm{H}]^{-}\right)$, respectively.

In addition, two megastigmanes identified as roseoside $\left(\mathrm{m} / \mathrm{z}\right.$ 387.20, $\left.[\mathrm{M}-\mathrm{H}]^{-}\right)(\mathbf{1 0})$ and 9-epi-blumenol C $\left(\mathrm{m} / \mathrm{z}\right.$ 371.90, $\left.[\mathrm{M}-\mathrm{H}]^{-}\right)(\mathbf{2 1})$ were also isolated.

\section{Anti-inflammatory activity}

In order to confirm the use of the decoction from leaves of cultivated M. urundeuva (AEMU) as a sustainable bioactive raw material to treat inflammatory diseases, it was evaluated the effect of this plant extract on activation/ degranulation of human neutrophils. These cells play an important role in the pathogenesis of various inflammatory diseases, ${ }^{19-21}$ such as asthma, rheumatoid arthritis and Parkinson disease.

The neutrophils are the major source of MPO in the circulation where this proteolytic enzyme has a central role in the neutrophil's bactericidal activity and it serves as an index of neutrophil activation. Thus, in order to investigate the anti-inflammatory effect of AEMU, we measured the MPO release level in human neutrophils stimulated by PMA in the absence or presence of the plant extract. Cells exposure to PMA induced a 3.5 times increase in MPO release as compared to the HBSS non-stimulated cells group (Figure 4). However, the addition of all concentrations of the AEMU (1-100 $\left.\mu \mathrm{g} \mathrm{mL}^{-1}\right)$ to neutrophils before PMA exposure significantly $(p<0.05)$ reduced MPO release since at a concentration of $10 \mu \mathrm{g} \mathrm{mL}^{-1}$. Interestingly, AEMU since at $50 \mu \mathrm{g} \mathrm{mL}^{-1}$ showed a comparable anti-inflammatory effect ( $82 \%$ of inhibition) when related to indomethacin (36 $\mu \mathrm{g} \mathrm{mL}-1: 72 \%$ of inhibition), a non-selective inhibitor of cyclooxygenase.

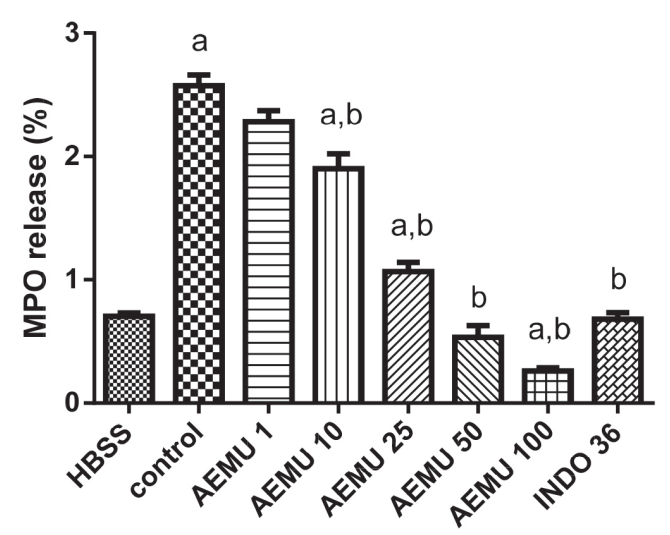

Figure 4. Effects of the aqueous extract from leaves of M. urundeuva (AEMU) on the release of human neutrophil myeloperoxidase (MPO) stimulated by phorbol myristate acetate. Data represent mean \pm standard error of the mean (S.E.M.). (a) vs. HBSS group; (b) vs. control group $(p<0.05$; ANOVA and Tukey as the post hoc test). AEMU 1, 10, 25, 50, 100: $1,10,25,50$ and $100 \mu \mathrm{g} \mathrm{mL}^{-1}$, respectively.
It was also investigated whether a possible toxic effect of the extract was involved in its anti-inflammatory activity in human neutrophils (Figure 5). The treatment of the human neutrophils with AEMU $\left(1,10,25,50\right.$ and $\left.100 \mu \mathrm{g} \mathrm{mL} \mathrm{L}^{-1}\right)$ did not reduce significantly the viability of cells when compared to control group (not treated) evaluated by the LDH activity (Figure 5). The LDH is a soluble cytoplasmic enzyme present in neutrophils being released into the extracellular space when occur loss of membrane integrity that results in either apoptosis or necrosis. ${ }^{22}$ Thus, the results suggest that the anti-inflammatory effect of AEMU seems to not be related to a toxic effect in the neutrophil plasma membrane.

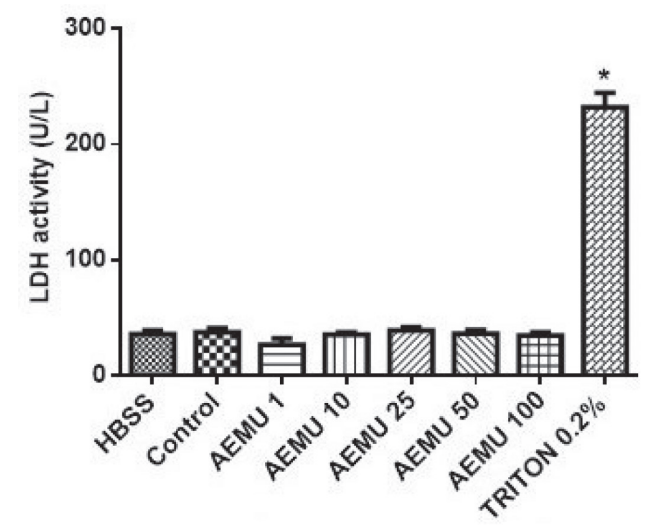

Figure 5. Evaluation of the aqueous extract from leaves of $M$. urundeuva (AEMU) toxicity measured by lactate dehydrogenase (LDH) release from human neutrophils. Data from until fourteen samples. *vs. control group. Results represent means \pm standard error of the mean (S.E.M.). $(p<0.05$; ANOVA and Tukey as the post hoc test). AEMU 1, 10, 25, 50, 100: 1, 10, 25,50 and $100 \mu \mathrm{g} \mathrm{mL}^{-1}$, respectively.

The presence of several phenols in AEMU including gallotannins $(\mathbf{9}, \mathbf{1 2}, 16$ and 20), flavonoid glycosides (11, 14, 15, 19, 22, 23 and 24), and flavonols like quercetin (13) certainly contributed for the anti-inflammatory effect of the plant extract. These hypothesis is supported by previous studies, ${ }^{17,23,24}$ some developed at our laboratory, that showed the anti-inflammatory activity of several phenols in human neutrophils, including flavonoids.

\section{Conclusions}

The phytochemical analysis of the decoction from leaves of cultivated $M$. urundeuva allowed the isolation and characterization of twenty-four compounds. This is the first report on the effective isolation, and spectroscopic characterization, of the secondary metabolites of the decoction from leaves of a cultivated specimen of M. urundeuva. This work confirms the presence of compounds $2,3,6-8,12,16-18$, and 20 in the ethanol extract from leaves of wild $M$. urundeuva previously suggested by an LCMS analysis dereplication study. ${ }^{10}$ On the other hand, 
compounds 1, 4, 5, 9-11, 13-15, 19, 21-23 and 24 are being reported for the first time for this plant. In addition, AEMU showed an anti-inflammatory effect modulating the human neutrophil pro-inflammatory response. This effect is possibly related with the presence of those several metabolites in the leaves of cultivated $M$. urundeuva.

\section{Supplementary Information}

Supplementary information is available free of charge at http://jbcs.sbq.org.br as PDF file.

\section{Acknowledgments}

The authors are grateful to Coordenação de Aperfeiçoamento de Pessoal de Nível Superior (CAPES), Conselho Nacional de Desenvolvimento Científico e Tecnológico (CNPq), Programa de Apoio a Núcleos de Excelência (PRONEX), Instituto Nacional do Semiárido (INSA) and Swiss National Science Foundation, for the fellowships and financial support.

\section{References}

1. Lorenzi, H.; Matos, F. J. A.; Plantas Medicinais no Brasil Nativas e Exóticas, $2^{\mathrm{a}}$ ed.; Instituto Plantarum de Estudos da Flora: Nova Odessa, Brasil, 2002.

2. de Albuquerque, U. P.; de Medeiros, P. M.; de Almeida, A. L. S.; Monteiro, J. M.; Lins Neto, E. M. F.; de Melo, J. G.; dos Santos, J. P.; J. Ethnopharmacol. 2007, 114, 325.

3. Napoleão, T. H.; Belmonte, B. R.; Pontual, E. V.; de Albuquerque, L. P.; Sá, R. A.; Paiva, L. M.; Coelho, L. C. B. B.; Paiva, P. M. G.; J. Stored Prod. Res. 2013, 54, 26.

4. Napoleão, T. H.; Pontual, E. V.; Lima, T. A.; Santos, N. D. L.; Sá, R. A.; Coelho, L. C. B. B.; Navarro, D. M. A. F.; Paiva, P. M. G.; Parasitol. Res. 2012, 110, 609.

5. Figueredo, F. G.; Lucena, B. F. F.; Tintino, S. R.; Matias, E. F. F.; Leite, N. F.; Andrade, J. C.; Nogueira, L. F. B.; Morais, E. C.; Costa, J. G. M.; Coutinho, H. D. M.; Rodrigues, F. F. G.; Pharm. Biol. 2014, 52, 560.

6. Cecílio, A. B.; Oliveira, P. C.; Caldas, S.; Campana, P. R. V.; Francisco, F. L.; Duarte, M. G. R.; Mendonça, L. A. M.; Almeida, V. L.; Braz. J. Pharm. 2016, 26, 197.

7. Mota, B. C. F.; Royo, V. A.; Fonseca, J. M. S.; dos Santos, A. C.; Melo Jr., A. F.; Menezes, E. V.; Esperandim, V. R.; Laurentiz, R. S.; J. Med. Plants Res. 2015, 9, 159.
8. Silva, V. C.; Napolitano, A.; Eletto, D.; Rodrigues, C. M.; Pizza, C.; Vilegas, W.; Eur. J. Mass Spectrom. 2011, 17, 365.

9. Nobre-Júnior, H. V.; Oliveira, R. A.; Maia, F. D.; Nogueira, M. A. S.; de Moraes, M. O.; Bandeira, M. A. M.; Andrade, G. M.; Viana, G. S. B.; Neurochem. Res. 2009, 34, 1066.

10. Viana, G. S. B.; Bandeira, M. A. M.; Moura, L. C.; Souza-Filho, M. V. P.; Matos, F. J. A.; Ribeiro, R. A.; Phytother. Res. 1997, 11,118 .

11. Botelho, M. A.; Rao, V. S.; Carvalho, C. B. M.; Bezerra-Filho, J. G.; Fonseca, S. G. C.; Vale, M. L.; Montenegro, D.; Cunha, F.; Ribeiro, R. A.; Brito, G. A.; J. Ethnopharmacol. 2007, 113, 471.

12. Souza, S. M. C.; Aquino, L. C. M.; Milach Jr, A. C.; Bandeira, M. A. M.; Nobre, M. E. P.; Viana, G. S. B.; Phytother. Res. 2007, 21, 220.

13. Albuquerque, R. J. M.; Leal, L. K. A. M.; Bandeira, M. A.; Viana, G. S. B.; Rodrigues, L. V.; Braz. J. Pharm. 2011, 21, 953.

14. Viana, G. S. B.; Bandeira, M. A. M.; Matos, F. J. A.; Phytomedicine 2003, 10, 189.

15. Margraff, R. In Centrifugal Partition Chromatographic Science Series, vol. 68; Foucault, A. P., ed.; Marcel Dekker: New York, 1994, p. 331-350.

16. Lucisano, M. Y.; Mantovani, B.; J. Immunol. 1984, 132, 2015.

17. de Araújo, A. L.; Magalhães, T. R.; de Andrade, D. E. U.; Silveira, E. R.; Azzolini, A. E.; Kabeya, L. M.; Lucisano-Valim, Y. M.; Vasconcelos, S. M.; Viana, G. S. B.; Leal, L. K.; Basic Clin. Pharmacol. Toxicol. 2013, 113, 363.

18. Boyum, A.; Scand. J. Clin. Lab. Invest., Suppl. 1968, 97, 77.

19. Gatto, E.; Carreras, M.; Pargament, G.; Riobo, N.; Reides, C.; Repetto, M.; Fernandez, P.; Llesuy, S. P. J.; Mov. Disord. 1996, 11, 261.

20. Wright, H.; Moots, R.; Edwards, S.; Nat. Rev. Rheumatol. 2014, $10,593$.

21. Monteseirin, J.; J. Allergy Clin. Immunol. 2009, 19, 340.

22. Chan, F.; Moriwaki, K.; de Rosa, M.; Methods Mol. Biol. 2013, $979,65$.

23. Nosál', R.; Drábiková, K.; Jančinová, V.; Mačičková, T.; Pečivová, J.; Perečko, T.; Harmatha, J.; Šmidrkal, J.; Physiol. Res. 2015, 64, Suppl. 4: S445.

24. Leal, L.; Canuto, K.; Costa, K. S.; Nobre-Júnior, H.; Vasconcelos, S.; Silveira, E.; Ferreira, M.; Fontenele, J.; Andrade, G.; Viana, G.; Basic Clin. Pharmacol. Toxicol. 2009, 104, 198.

Submitted: November 4, 2018 Published online: April 10, 2019 